\title{
Zmiany źródeł utrzymania ludności rolniczej ${ }^{1}$
}

\section{Wstęp}

Wraz ze zmianą systemu społeczno-gospodarczego w Polsce pogorszeniu uległy ekonomiczne warunki gospodarowania w rolnictwie. Znaczne obniżenie dochodów rolniczych w roku 1990 pogłębiło się jeszcze po roku 1996. Efektem powyższych zmian było poszukiwanie przez ludność rolniczą dodatkowych źródeł utrzymania.

\section{Źródka dochodów ludności rolniczej}

Spadek dochodów z produkcji rolniczej powoduje zmniejszanie się udziału rolnictwa w gospodarce narodowej. Wyrazem tego jest coraz mniejszy odsetek gospodarstw utrzymujących się głównie z rolnictwa, a jednocześnie rosnąca liczba tych, dla których inne, nierolnicze źródła nabierają coraz większego znaczenia (tab. 1).

\section{Tabela 1}

Struktura indywidualnych gospodarstw rolnych według głównego źródła utrzymania (tł. $51 \%$ i więcej) w roku 1996 i 2002

\begin{tabular}{|l|c|c|}
\hline Wyszczególnienie & $\mathbf{1 9 9 6}$ & $\mathbf{2 0 0 2}$ \\
\hline Działalność rolnicza & 37,6 & 20,8 \\
\hline Praca najemna & 21,7 & 27,1 \\
\hline Emerytura lub renta & 21,3 & 30,9 \\
\hline Działalność pozarolnicza & 3,2 & 5,8 \\
\hline Kilka źródeł $^{*}$ & 16,2 & 15,4 \\
\hline
\end{tabular}

*żaden $z$ dochodów nie stanowił $51 \%$ wszystkich uzyskanych

Źródło: Powszechny Spis Rolny 1996 i 2002. GUS.

\footnotetext{
${ }^{\mathrm{I}}$ Na podstawie danych spisów powszechnych z lat 1996 i 2002.
} 
Podczas gdy w roku 1996 działalność rolnicza stanowiła główne źródło utrzymania dla 37,6\% indywidualnych gospodarstw rolnych, to w roku 2002 było to już tylko niespełna $21 \%$. Kolejnych blisko $55 \%$ gospodarstw uzyskiwało również dochody z produkcji rolniczej, przy czym miały one dla nich mniejsze znaczenie - nie stanowiły głównego źródła dochodów. Ponadto, w roku 1996 największy odsetek ludności rolniczej utrzymywał się głównie $\mathrm{z}$ dochodów uzyskiwanych $\mathrm{z}$ produkcji rolniczej, kolejne miejsce stanowiły dochody $z$ pracy najemnej, a następne otrzymywana emerytura lub renta. Dochody uzyskiwane $\mathrm{w}$ wyniku prowadzenia pozarolniczej działalności gospodar$\mathrm{czej}^{2}$ stanowiły główne źródło utrzymania tylko dla 3,2\% gospodarstw indywidualnych.

W roku 2002 wystapił nie tylko spadek udziału gospodarstw indywidualnych, których ludność utrzymywała się głównie z działalności rolniczej. Nastąpiła też zasadnicza zmiana struktury gospodarstw według głównego źródła utrzymania. Największy odsetek ludności rolniczej (blisko 31\%) utrzymywał się ze źródeł socjalnych - rent lub emerytur. Kolejne miejsce zajmowały gospodarstwa, w których główne źródło dochodów stanowiła praca najemna (ponad $27 \%$ ), a tylko niespełna $21 \%$ utrzymywało się głównie z produkcji rolniczej. Największy wzrost (80\%) w stosunku do roku 1996 wystąpił w gospodarstwach, których głównym źródłem utrzymania była działalność pozarolnicza, mimo że stanowiły one tylko $6 \%$ gospodarstw indywidualnych.

Bardzo interesujący jest również fakt największego zainteresowania działalnością pozarolniczą wśród gospodarstw o największym obszarze (rys. 1). Zarówno w roku 1996, jak i w 2002 największy udział gospodarstw z działalnością pozarolniczą (ok. $46 \%$ w 1996 r. i ponad 48\% w 2002 r.) wystapił w grupie gospodarstw o powierzchni przekraczającej 200 ha UR. Nieco mniejszy odsetek takich gospodarstw odnotowano w grupie, gdzie powierzchnia gospodarstwa wynosiła 50-200 ha UR. Kolejne miejsce pod tym względem zajmowały gospodarstwa o powierzchni UR nieprzekraczającej 2 ha. Najmniejszy odsetek gospodarstw z działalnością pozarolniczą był wśród gospodarstw średnich obszarowo (5-20 ha UR). Są to gospodarstwa, których obszar oraz poziom wyposażenia w środki produkcji pozwalają na wytworzenie produkcji rolniczej zapewniającej odpowiednie dochody.

Zainteresowanie działalnością pozarolniczą wśród gospodarstw o małym obszarze spowodowane jest chęcią uzyskania dodatkowych dochodów, gdyż produkcja rolnicza jest tu na niewystarczającym poziomie. Sa to jednak gospo-

\footnotetext{
${ }^{2}$ Praca na własny rachunek poza gospodarstwem rolnym (np. własne zakłady przemysłowe, rzemieślnicze, handlowe i usługowe, zatrudniające lub niezatrudniające pracowników najemnych) [Pozarolnicza... 2003, s. 12].
} 
darstwa, które dysponują zbyt małymi środkami kapitałowymi potrzebnymi do rozwoju działalności pozarolniczej, szczególnie wykorzystującej zasoby gospodarstwa rolniczego, bądź nierolniczej działalności produkcyjnej. Ponadto, w tej grupie gospodarstw jest znaczny odsetek ludności utrzymującej się ze źródeł socjalnych, co również nie sprzyja rozwojowi działalności pozarolniczej.

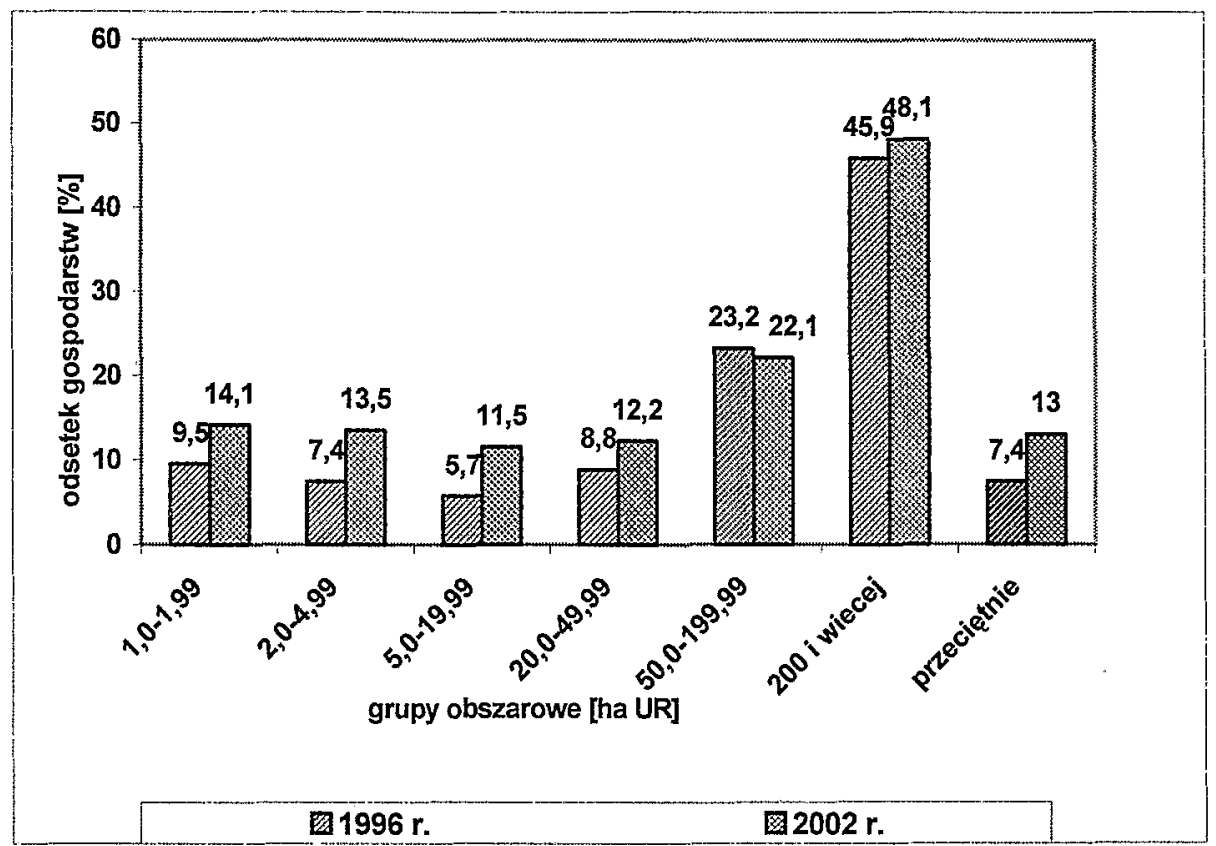

\section{Rysunek 1}

Udział gospodarstw $z$ działalnością pozarolniczą w ogólnej liczbie indywidualnych gospodarstw rolnych w wyodrębnionych grupach obszarowych [\%] Żódło: Powszechny Spis Rolny 1996 i 2002. GUS.

$\mathrm{Na}$ duże zainteresowanie działalnością pozarolniczą wśród gospodarstw rolnych o dużej powierzchni wskazują również badania innych autorów [Sikorska-Wolak 2000, Wiatrak 2002]. Niektórzy widzą nawet pewną prawidłowość w tym względzie [Kapusta 2003]. Gospodarstwa te lokują część swego kapitału w działy pozarolnicze, z których otrzymują dochody na rzecz gospodarstw domowych [Michna, Wrzochalska 1998]. Niektórzy uważają [Józwiak 2004], że część tych gospodarstw prowadzi de facto jedynie działalność pozarolnicza, a posiadane gospodarstwo umożliwia ograniczenie ponoszonych kosztów społecznych bądź może być wykorzystane do spekulacji gruntami. Są to gospodarstwa, które stać na prowadzenie działalności dodatkowej wymagającej dużych nakładów inwestycyjnych, m.in. nierolniczej działalności produkcyjnej. 
Niemal wszystkie wyodrębnione grupy obszarowe wykazały wzrost odsetka gospodarstw prowadzących działalność pozarolnicza, co świadczy o znaczeniu dochodów $z$ tej działalności dla gospodarstw domowych rodzin rolniczych. W przyszłości należy spodziewać się dalszego wzrostu liczby gospodarstw, dla których działalność ta będzie istotnym elementem w strukturze dochodów. Ważnym czynnikiem jest tu również wszelkiego rodzaju pomoc skierowana do rolników, wśród której wymienić należy dofinansowanie ze środków UE (m.in. program Leader + ).

\section{Kryterium przeważającego dochodu}

W opracowaniu wyników PSR '96 GUS wyodrębnił siedem następujących typów gospodarstw domowych z użytkownikiem gospodarstwa indywidualnego:

I - rolnicze, tzn. takie, w których dochody z działalności rolniczej stanowią więcej niż 50\% ogółu dochodów gospodarstwa domowego;

II - rolniczo-pracownicze, tj. takie, że dochody z działalności rolniczej i pracy najemnej stanowią ponad $50 \%$ ogółu dochodów gospodarstwa domowego, a dochody rolnicże są wyższe od dochodów z pracy najemnej;

III - pracownicze i pracowniczo-rolnicze - dochody z pracy najemnej lub łączne dochody $z$ pracy najemnej i działalności rolniczej stanowią ponad $50 \%$, przy czym dochody z pracy najemnej przewyższają dochody rolnicze;

IV - gospodarstwa emerytów i rencistów - źródła te stanowią więcej niż 50\% ogółu dochodów gospodarstwa domowego;

$\mathrm{V}$ - z pozarolniczą działalnością gospodarcz̨ tzn. takie, w których dochody z nierolniczej działalności na własny rachunek stanowią więcej niż $50 \%$ ogółu dochodów gospodarstwa domowego;

VI - utrzymujące się z niezarobkowych źródeł (innych niż emerytura i renta) dochody z tych źródeł stanowią więcej niż 50\% ogółu dochodów gospodarstwa domowego;

VII - gospodarstwa pozostałe, tj. takie, które nie mieszczą się w poprzednich grupach.

W strukturze gospodarstw indywidualnych spośród wyodrębnionych typów gospodarstw dominowały gospodarstwa rolnicze (typ I), chociaż ich odsetek zmalat i wynosił w roku 2002 tylko niespełna $30 \%$ (rys. 2). Źródło: Powszechny Spis Rolny 1996 i 2002. GUS. 


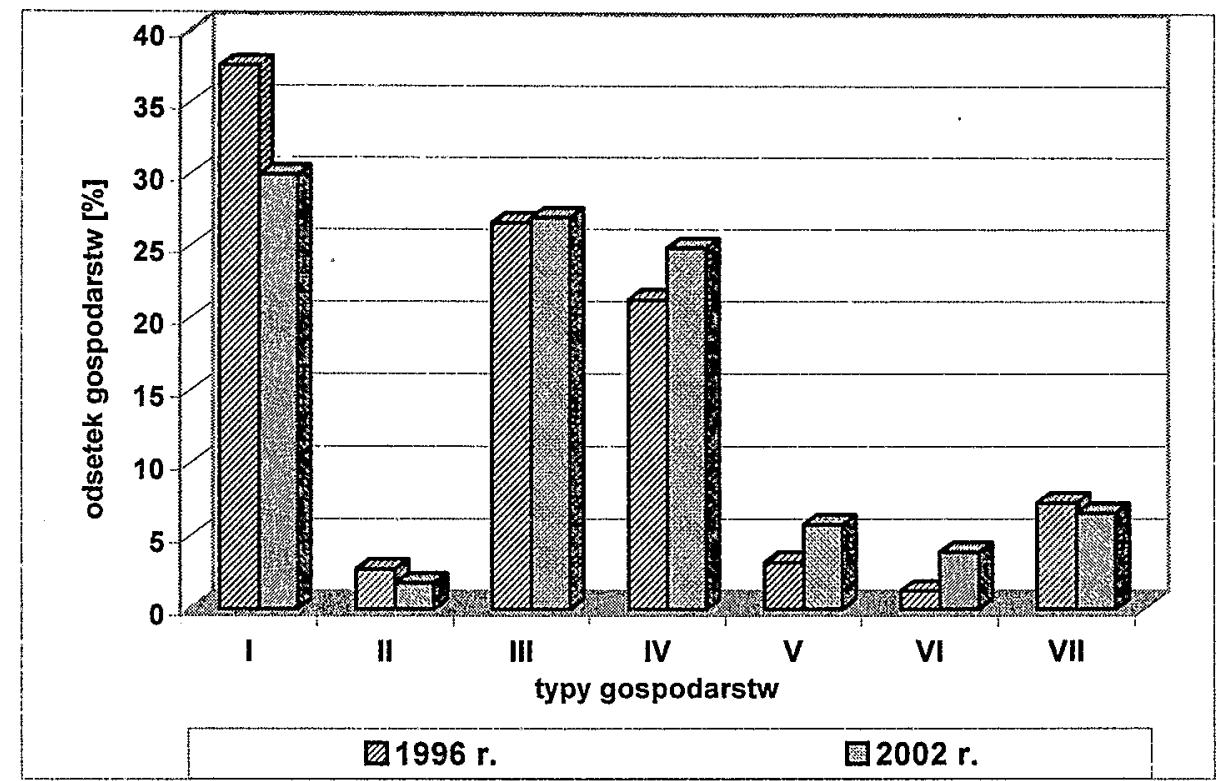

\section{Rysunek 2}

Struktura gospodarstw indywidualnych według typu spoleczno-ekonomicznego gospodarstwa domowego

Źródło: Powszechny Spis Rolny 1996 i 2002 . GUS.

Kolejną ważną grupę (powyżej 25\%) stanowiły gospodarstwa pracownicze i pracowniczo-rolnicze (typ III), a więc takie, w których przeważały dochody uzyskiwane z pracy zarobkowej. W roku 2002 odnotowano niewielki wzrost (poniżej 1 p. p.) odsetka tych gospodarstw.

Gospodarstwa emerytów i rencistów stanowiły przeszło $21 \% \mathrm{w}$ roku 1996 i aż blisko $25 \% \mathrm{w}$ roku 2002 . Wzrósł również znacznie, przeszło trzykrotnie, udział gospodarstw utrzymujących się z pozostałych źródeł niezarobkowych. Łącznie zatem blisko $29 \%$ gospodarstw rolniczych stanowi głównie zaplecze mieszkaniowe, ludność z tych gospodarstw jest utrzymywana ze źródeł socjalnych, a niepokoi wzrost jej odsetka. Sytuacja ta częściowo wpływa również negatywnie na przemiany strukturalne obszarów wiejskich.

Interesujący jest fakt, że o ile w roku 1996 najmniejszy był odsetek gospodarstw niezarobkowych (typ VI), o tyle w roku 2002 pozycję tę zajęły gospodarstwa rolniczo-pracownicze. Niewielki udział tych ostatnich tłumaczą częściowo trudności znalezienia pracy zarobkowej przez rolników i pogodzenia jej $\mathrm{z}$ działalnością rolnicza, która $w$ tej grupie ma przynosić wyższe dochody niż praca zarobkowa.

Reasumując, tylko około $32 \%$ gospodarstw (rolnicze i rolniczo-pracownicze) należy uznać za gospodarstwa domowe rolnicze, gdyż przeważa 
tu lub dominuje właśnie dochód z produkcji rolniczej. Gospodarstwa te skupiają około $40 \%$ ogółu ludności żyjącej w gospodarstwach domowych z użytkownikiem indywidualnego gospodarstwa rolnego.

Niespełna $60 \%$ gospodarstw indywidualnych prowadzących działalność rolniczą uzyskuje z niej dochody nieprzekraczające 30\% dochodu ogólnego gospodarstwa domowego.

\section{Wnioski}

1. W latach 1996-2002 nastąpiły zmiany źródeł utrzymania ludności rolniczej, wśród których zmalało znaczenie dochodów rolniczych.

2. Działalność rolnicza stanowiła w roku 2002 główne źródło dochodów ludności tylko niespełna $21 \%$ indywidualnych gospodarstw rolniczych.

3. Tylko około $32 \%$ gospodarstw można uznać za gospodarstwa domowe rolnicze (przeważa lub dominuje dochód z produkcji rolniczej).

4. Wzrósł odsetek gospodarstw emerytów i rencistów.

5. Ludność blisko $29 \%$ gospodarstw domowych z użytkownikiem indywidualnego gospodarstwa rolnego utrzymywała się w roku 2002 ze źródeł socjalnych.

6. Wzrósł znacznie odsetek gospodarstw, w których główne źródło utrzymania stanowi pozarolnicza działalność gospodarcza.

\section{Literatura}

JÓZWIAK W., 2004: Strategie postępowania posiadaczy gospodarstw rolnych i ich pozarolnicze formy aktywności gospodarczej w latach 1996-2002. Roczniki Naukowe SERiA, Tom VI, Zeszyt 3. Wieś Jutra, Warszawa.

KAPUSTA F., 2003: Ewolucja funkcji polskiej wsi w latach 1945-2001. W: Wyzwania stojące przed rolnictwem i wsią u progu XXI wieku. Red. Kutkowska B. Prace Naukowe, nr 980. Akademia Ekonomiczna im. Oskara Langego we Wrocławiu, Wrocław.

MICHNA W., WRZOCHALSKA A., 1998: Główne kierunki przeobrażeń w rolnictwie w latach dziewięćdziesiątych. IERiGŻ, Warszawa.

Powszechny Spis Rolny 1996. GUS 1997, Warszawa.

Powszechny Spis Rolny 2002. GUS 2003, Warszawa.

Pozarolnicza działalność gospodarstw rolnych. GUS 2003, Warszawa.

SIKORSKA-WOLAK I., 2000: Przedsiębiorczość w ujęciu normatywnym, funkcjonalnym i opisowym. W: Rola doradztwa rolniczego w rozwoju przedsiębiorczości zespołowej rolników. Red. Sikorska-Wolak I., Krzyżanowska K. Konferencja naukowa, Wydawnictwo SGGW, Warszawa. 
WIATRAK A.P., 2002: Sytuacja dochodowa polskiego rolnictwa w latach dziewięćdziesiątych. W: Transformacja rolnictwa polskiego i ukraińskiego w latach 90. Red. Klepacki B., Czerewko G. Wieś Jutra, Warszawa.

\section{Changes in Income Sources of the Agricultural Population}

\section{Abstract}

The paper includes an analysis of changes in income sources of private agricultural farms. The work is based on numeric data from National Census of People from 1996 and 2002.

The share of agricultural population financially dependent on agricultural production decreased. The share of agricultural population made a living by social incomes increased at the same time. 
